\title{
Model Kepemimpinan Visioner pada Yayasan Sasmita Jaya Group di Provinsi Banten
}

\author{
Syarifah Ida Farida ${ }^{1}$; Iskandar Zulkarnain ${ }^{2}$ \\ Universitas Pamulang, dosen01477@unpam.ac.id
}

\section{ARTICLES INFORMATION}

\section{ABSTRACT}

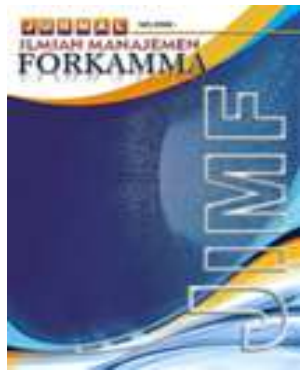

\section{JURNAL ILMIAH MANAJEMEN FORKAMMA}

Vol.4, No.2, Maret 2021 Halaman : $104-120$

C LPPM \& FORKAMMA

Prodi Magister Manajemen UNVERSITAS PAMULANG

ISSN (online) : 2599-171X ISSN (print) : :2598-9545

Keyword :

Kepemimpinan; visioner.

JEL. classification : M12, M54

Contact Author :

PRODI

MAGISTER MANAJEMEN \& FORKAMMA UNPAM

JL.Surya Kencana No.1 Pamulang

Tangerang Selatan - Banten

Telp. (021) 7412566, Fax (021) 7412491 Email :

jurnalforkamma.unpam@gmail.com
Penelitian ini bertujuan untuk mengetahui model kepemimpinan visioner pada Yayasan Sasmita Jaya Group di Provinsi Banten. Jenis penelitian ini adalah metode kualitatif. Lokasi penelitian dilakukan di Yayasan Sasmita Jaya Group di Provinsi Banten. Pengumpulan data menggunakan teknik observasi, wawancara, dan dokumentasi. Hasil penelitian menunjukkan Model kepemimpinan pada Yayasan Sasmita Jaya Group yang dipimpin oleh Bapak $\operatorname{Dr}(\mathrm{HC})$ Darsono memiliki beberapa karakteristik yaitu empati, sederhana, rendah hati, kreatif, dan entrepreneurship. Tipikal tersebut yang membuat pak Darsono sukses dalam membangun Unpam dan usahanya yang lain. Dengan model kepemimpinan tersebut, pak Darsono memiliki komitmen tinggi dan professional dalam menjalankan tugas. Dengan model itu pula, la dapat berlaku adil dalam mengambil keputusan. Yayasan Sasmita jaya semakin eksis disebabkan kepemimpinan visioner pak Darsono. Kepemimpinan visioner pak Darsono yang paling esensial adalah memiliki konsep "ruh berbagi". Konsep tersebut sudah diterapkan lama sejak ia belum membangun usaha lainnya. Bahkan konsep tersebut sudah menjadi habit di masa muda beliau. Konsep tersebut memiliki aspek humanis yang tinggi dan sesuai dengan ajaran agama

The purpose of this study is to identify a visionary leadership model at Yayasan Sasmita Jaya Group in Banten Province. The method of the research is a qualitative method. The research location is conducted at Yayasan Sasmita Jaya Group in Banten Province. The results showed that Visionary Leadership of Yayasan Sasmita Jaya Group has several characteristics, namely empathy, simplicity, humility, creativity, and entrepreneurship. This model make Darsono successful in developing Unpam and other businesses. It makes Darsono has highly committed and professional in doing his job. He also can be fairly in making decision. Yayasan Sasmita Jaya has been increasingly existed since Darsono handle it. Darsono's most essential visionary leadership to build the concept of "sharing spirit". This concept has been applied for a long time since he has not built any other businesses. In fact, this concept has become a habit in his youth. This concept has a high humanist aspect and is in accordance with religous teachings. 


\section{A. PENDAHULUAN}

Pemimpin merupakan ujung tombak keberhasilan suatu organisasi, karena yang menentukan tujuan, visi dan misi dalam suatu organisasi atau perusahaan. Pemimpin bukanlah suatu bakat yang dimiliki oleh orang tertentu saja, tetapi pemimpin adalah kelebihan yang sudah Allah SWT berikan kepada semua manusia di muka bumi ini. Kepemimpinan yang ada di dalam diri manusia harus terus diasah dan ditambah ilmunya melalui pendidikan formal dan informal. Pendidikan yang diwajibkan pemerintah saat ini dari Sekolah Dasar (SD) sampai Sekolah Menengah Kejuruan (SMK) atau Atas (SMA). Hal ini pun disadari oleh Menteri Pendidikan dan Kebudayaan yaitu Bapak Muhadjir yang menyatakan bahwa wajib belajar 12 tahun belum maksimal (Prastiwi, 2019).

Pada zaman revolusi industri 4.0 dibutuhkan pendidikan yang lebih tinggi melalui perguruan tinggi diantaranya Perguruan Tinggi Negeri dan Swasta. Berdasarkan informasi dari forlap ristekdikti saat ini perguruan tinggi di Indonesia yang ada di bawah Kemenristekdikti berjumlah 4.707 yang di antaranya terdiri dari Akademi, Politeknik, Sekolah Tinggi, Institut, Universitas, dan Akademi komunitas. Sedangkan data dari Kemenristekdikti bahwa banyak perguruan tinggi dari tahun 2015 sampai dengan tahun 2019 yang ditutup sebanyak 130, dikarenakan ada beberapa alasan di antaranya kurangnya jumlah mahasiswa (Mediani, 2019).

\begin{tabular}{|lll} 
& Tabel 1 Perguruan Tinggi di Indonesia Tahun 2019 \\
\hline No & Perguruan Tinggi & Jumlah \\
\hline $\mathbf{1}$ & Akademi & 995 \\
$\mathbf{2}$ & Politeknik & 295 \\
$\mathbf{3}$ & Sekolah Tinggi & 2.544 \\
$\mathbf{4}$ & Institut & 230 \\
$\mathbf{5}$ & Universitas & 619 \\
$\mathbf{6}$ & Akademik Komuniktas & 24 \\
& Total & $\mathbf{4 . 7 0 7}$ \\
\hline
\end{tabular}

Sumber: http://forlap.ristekdikti.go.id/perguruantinggi/homegraphpt (2019)

Dari data yang didapatkan melalui Statistika Pendidikan Tinggi di Indonesia dan Forlap Ristekdikti dapat dilihat bahwa pada tahun 2016 jumlah perguruan tinggi di Indonesia di bawah Kemenristekdikti sebanyak 4.445 dan mengalami penurunan di tahun 2017 yaitu sebesar 3.276 dan naik kembali jumlahnya di tahun 2019 sebanyak 4.707, yang dapat dilihat pada Tabel 2.

\begin{tabular}{lll}
\multicolumn{2}{l}{ Tabel } & 2 Perguruan Tinggi di Indonesia Tahun 2016 s.d 2019 \\
\hline No & Tahun & Jumlah PT di Indonesia \\
\hline $\mathbf{1}$ & 2016 & 4.445 \\
\hline $\mathbf{2}$ & 2017 & 3.276 \\
\hline $\mathbf{3}$ & 2018 & 3.293 \\
\hline $\mathbf{4}$ & 2019 & 4.707 \\
\hline
\end{tabular}

Sumber: Statistik Pendidikan Tinggi Indonesia dari forlap.ristekdikti.go.id (2019)

Dalam hal ini pemimpin mempunyai peranan yang sangat dibutuhkan dalam mengelola sumber daya yang ada. Apabila penerimaan mahasiswa lebih sedikit dibandingkan pengeluaran, maka akan berimbas menurunnya pemasukan untuk perguruan tinggi tersebut. Berbeda dengan Universitas Pamulang (UNPAM) yang berdiri pada tahun 2000 dengan biaya yang sangat terjangkau, tanpa uang pembangunan tetapi 
terus membangun gedung yang besar di daerah Pamulang dengan jumlah mahasiswa kurang lebih 80.000 orang.

Selain itu Universitas Pamulang memiliki dosen yang cukup banyak sesuai dengan rasio yang harus dipenuhi berdasarkan peraturan pemerintah yaitu 1: 45 untuk sosial dan 1: 30 untuk ilmu sains dan teknologi. Data yang peneliti dapatkan bahwa jumlah mahasiswa 72.571 dan jumlah dosen tetap yang dimiliki Universitas Pamulang sebanyak 1.968.

Tabel 3 Data Fakultas dan Program Studi di Universitas Pamulang Pelaporan Tahun Akademik 2018/2019

\begin{tabular}{|c|c|c|c|c|c|c|}
\hline No. & Fakultas & Program Studi & Program & $\begin{array}{l}\text { Jumlah } \\
\text { Mahasiswa } \\
\text { Aktif }\end{array}$ & $\begin{array}{l}\text { Jumlah } \\
\text { Dosen } \\
\text { Tetap }\end{array}$ & $\begin{array}{l}\text { Rasio } \\
\text { Dosen } \\
\text { Tetap/ } \\
\text { Jumlah } \\
\text { Mahasiswa }\end{array}$ \\
\hline \multirow[t]{2}{*}{1} & \multirow{2}{*}{ Hukum } & 1. Ilmu Hukum & Sarjana & 5.537 & 141 & $1: 39.3$ \\
\hline & & 2. IImu Hukum & Magister & 407 & 13 & $1: 31.3$ \\
\hline \multirow[t]{5}{*}{2.} & \multirow[t]{5}{*}{ Ekonomi } & 3. Manajemen & Sarjana & 24.064 & 626 & $1: 39.3$ \\
\hline & & 4. Akuntansi & Sarjana & 11.639 & 333 & $1: 35$ \\
\hline & & 5. Akuntnasi & Diploma & 1.554 & 48 & $1: 32.4$ \\
\hline & & 6. Sekretari & Diploma & 1.228 & 38 & $1: 32.3$ \\
\hline & & 7. Manajemen & Magister & 934 & 23 & $1: 40.6$ \\
\hline 3. & MIPA & 8. Matematika & Sarjana & 795 & 26 & $1: 30.6$ \\
\hline \multirow[t]{2}{*}{4.} & $\begin{array}{l}\text { Keguruan } \\
\text { dan IImu }\end{array}$ & $\begin{array}{l}\text { 9. Pendidikan } \\
\text { Ekonomi }\end{array}$ & Sarjana & 1.457 & 47 & $1: 31$ \\
\hline & Pendidikan & $\begin{array}{l}\text { 10. Pendidikan } \\
\text { Pancasila dan } \\
\text { Kewarganegaraan }\end{array}$ & Sarjana & 1.363 & 39 & $1: 34.9$ \\
\hline \multirow[t]{2}{*}{5.} & \multirow[t]{2}{*}{ Sastra } & 11. Sastra Indonesia & Sarjana & 1.625 & 36 & $1: 45.1$ \\
\hline & & 12. Sastra Inggris & Sarjana & 3.457 & 84 & $1: 41.2$ \\
\hline \multirow[t]{6}{*}{6.} & \multirow[t]{6}{*}{ Teknik } & 13. Teknik Elektro & Sarjana & 2.048 & 71 & $1: 28.8$ \\
\hline & & 14. Teknik Industri & Sarjana & 2.713 & 94 & $1: 28.9$ \\
\hline & & 15. Teknik Informatika & Sarjana & 10.481 & 240 & $1: 43.7$ \\
\hline & & 16. Teknik Kimia & Sarjana & 537 & 22 & $1: 24.4$ \\
\hline & & 17. Teknik Mesin & Sarjana & 2.732 & 87 & $1: 31.4$ \\
\hline & & Total & & & 1.968 & 72.571 \\
\hline
\end{tabular}

Sumber: forlap.ristekdikti.go.id (2019)

Hal ini tidak luput dari kepemimpinan ketua Yayasan Sasmita Jaya Group yaitu Bapak Dr. (HC) Darsono yang telah membangun Universitas Pamulang, Sekolah Tinggi IImu Kesehatan Widya Dharma Husada dan membangkitkan kembali Universitas yang hampir tutup diantaranya Sekolah Tinggi Manajemen Informatika dan Komputer (STMIK) Eresha dan STIKES WDH dan memiliki bisnis lainnya selain di bidang pendidikan.

Pada masa pandemi Covid-19 ini banyak perguruan tinggi yang mengalami penurunan sangat drastis dikarenakan banyak yang di PHK, pengangguran semakin meningkat, krisis kesehatan dan penuranan daya beli masyarakat dikarenakan krisis global di seluruh dunia. Banyak perguruan tinggi yang ditutup atau menutup kegiatan perkuliahan mereka disebabkan banyak mahasiswa yang mengundurkan diri karena krisis ekonomi dan menurunnya jumlah mahasiswa yang mendaftar. Sehingga perguruan tinggi tidak sanggup lagi membayar gaji dosen dan karyawan serta operasonal kampus.

Selain perguruan tinggi banyak bisnis lainnya yang merumahkan pekerjanya dikarenakan pandemi Covid-19 ini, dari data yang diperoleh sudah 6 juta warga Republik 
Indonesia yang terkena Dirumahkan dan Pemutusan Hubungan Kerja (PHK) (Indraini, 2020).

Berbeda dengan Yayasan Sasmita Jaya Group yang memiliki beberapa bidang usaha bisnis dan pendidikan yang terus mempekerjakan karyawannya dan tidak memutus hubungan kerja pegawai yang telah mengabdi kepada yayasan tersebut. Dengan biaya yang sangat terjangkau dan tidak membebankan uang gedung kepada mahasiswanya, yayasan ini terus membangun dan memberikan fasilitas yang lengkap untuk para mahasiswa dan masyarakat sekitarnya. Sedangkan Perguruan Tinggi Swasta (PTS) yang hanya mengandalkan dana dari mahasiswa banyak yang tutup dan mengurangi pegawainya untuk meminimalisir pengeluaran lainnya. Berdasarkan desksripsi latar belakang tersebut maka peneliti tertarik untuk meneliti dengan judul "Model Kepemimpinan Visioner pada Yayasan Sasmita Jaya Group di Provinsi Banten".

\section{B. KAJIAN LITERATUR}

Kepemimpinan disebut juga leadership yang memiliki arti being a leader power of leading; the qualities of leader, yaitu seseorang dalam memimpin dan memberikan pengarahan memiliki kekuatan atau kualitas terhadap apa yang dipimpinnya untuk mencapai suatu tujuan yang telah ditetapkan. Sedangkan dalam arti bahasa Indonesia bisa diartikan sebagai pelopor, pembina, panutan, pembimbing, penggerak, ketua, kepala, pengurus, penghulu, kepala, penuntun dan sebagainya (Hidayat \& Wijaya, 2017).

Kegiatan mempengaruhi orang lain baik perorangan maupun kelompok bisa disebut juga sebagai kepemimpinan. Kepemimpinan tidak diwajibkan terikat dan tidak dibatasi oleh tata krama birokrasi serta aturan-aturan (Farida \& Anjani, 2019). Kepemimpinan bisa dilakukan kapan saja, dimana saja, yang terpenting bisa menunjukkan kemampuannya mempengaruhi perilaku orang lain untuk mencapai tujuan tertentu (Thoha, 2017).

Pemimpin harus bisa memberikan pengaruh yang positif untuk orang lain dengan motivasi dan semangat dalam menyelesaikan pekerjaannya sesuai dengan target yang telah ditentukan. Tanpa kepemimpinan diibaratkan tubuh tanpa kepala, sehingga sangat penting dalam kehidupan manusia. Di dalam organisasi contohnya kepemimpinan yang diberikan kepada karyawan sehingga kinerja meningkat dan mendapatkan keuntungan untuk perusahaan. Pemimpin juga memberikan pengaruhnya melalui narulinya, sikapnya dan kepribadiannya sehingga orang yang dipimpinnya dapat bekerjasama dan berkolaborasi untuk mencapai tujuan. Sehingga pemimpin harus memiliki kreativitas dan inovasi yang tinggi dalam memimpin bawahannya (Wijaya \& Rifa'i, 2016).

Selain itu, leading atau memimpin adalah memberikan rangsangan untuk berkinerja tinggi kepada orang lain, diantaranya dengan memberikan motivasi dan berkomunikasi dengan karyawan baik kelompok mapun individu (Farida \& Khair, 2019)

Sedangkan kepemimpinan visoner adalah kepemimpinan yang menggambarkan tentang masa depan yang diinginkan bersama. Kepemimpinan visioner memiliki kemampuan dalam merumuskan, mensosialisasikan, mencipta, mengimplementasikan dan mentransformasikan ide-ide yang sempuran berasal dari diri sendiri atau hasil interaksi sosial antar-anggota pada masa depan yang harus diraih atau diwujudkan sebagai tujuan organisasi yang harus diraih atau diwujudkan melalui komitmen semua personil untuk masa depan. Karakteristik kepemimpinan visioner untuk mengetahui gamabran perilaku dan sikap pemimpin yang berorietnasi pada visi (Ma'sum, 2019).

Kepemimpinan visioner melibatkan kesanggupan, kemampuan, kepiawaian yang luar biasa untuk menawarkan kesuksesan dan kejayaan pada masa depan. Seorang pemimpin visioner mampu mengantisipasi segala kejadian yang mungkin timbul, mengelola masa depan dan mendorong orang lain untuk berbuat dengan cara-cara yang tepat. Hal itu berarti, pemimpin yang visioner mampu melihat tantangan dan peluang sebelum keduanya terjadi sambil kemudian memposisikan organisasi mencapai tujuantujuan terbaiknya. 
Kepemimpinan visioner menunjukkan kepemimpinan berkualitas dan memiliki integritas pribadi, antusiasme terhadap organisasi yang dipimpinnya, membangun iklim organisasi yang kondusif, dan tegas dalam mengambil tindakan maupun keputusan. Kemampuan kepemimpinan visioner yaitu membuat visi dan perencanaan yang jelas dengan menggambarkan sasaran atau tujuan pokok apa yang akan diraih. Visi pemimpin menggambarkan mengenai masa depan organisasi yang dipimpinnya, yaitu memiliki pandangan yang jauh ke depan dan mendalam serta menerobos batas-batas fisik, waktu, dan tempat (Sagala S. , 2018).

Karakteristik dan ciri pemimpin efektif dan visioner adalah mampu beradaptasi terhadap kondisi yang berubah-ubah dengan terus-menerus berkelanjutan. Pemimpin visioner memiliki visi yang dapat diukur dan jelas dan spesifik sebagai ekspresi mengenai keadaan masa depan yang diinginkan perusahaan atau organisasi menggunakan kesempatan dan peluang yang mungkin diraih.

Kepemimpinan visioner memiliki kemampuan mengartikulasi, menciptakan sebuah visi yang realistik dan ke depan, menarik dan dapat dipercaya untuk memperbaiki situasi yang terjadi saat ini. Visi ini menurut Robbins dan Coulter (2009: 161) jika ditentukan dan diimplementasi dengan tepat, dapat menciptakan tenaga luar biasa, sehingga bisa melompat jauh ke masa depan (visioner). Sedangkan visi atau wawasan itu sendiri adalah pandangan yang merupakan intisari dan kristalisasi dari kebiasaan (self efficacy), kemampuan (competency), kebolehan (ability), dan dalam mengobservasi, menganalisis, dan memaknai mengandung intisari dari arah dan tujuan, misi, norma dan nilai yang utuh (Sagala S. , 2018).

Kesukesan suatu organisasi atau perusahaan tentu ada hubungannya dengan prinsip dan peran pemimpin yang visioner yaitu: (Hauen, 2015)

1) Mengkomunikasikan arah visi yaitu memberikan pemahaman dan arahan, menunjukkan kesesuaian (congruence) antara visi dan cara-cara mencapainya, menciptakan dukungan dan penerimaan, dan menciptakan keselarasan (alignment) dengan visi pribadi lainnya;

2) Menciptakan pemahaman menyeluruh mengenai sistem yaitu menciptakan pemahaman seluruh sistem, menciptakan kesesuaian (congruence) dalam arti luas, menciptakan kerja sama dan pembelajaran lintas bidang, dan menciptakan keselarasan (alugnment) di antara kelompok minat; dan

3) Berbicara yaitu menunjukkan nilai-nilai organisasi, menunjukkan perilaku profesional yang sesuai (congruence), menciptakan sistem kepercayaan dan keyakinan yang produktif dengan menghilangkan kepercayaan dan keyakinan yang membatasi (menghambat), dan menciptakan keserasian (alignment) antara nilai-nilai karyawan dan nilai-nilai organisasi.

Pemimpin visioner memiliki pengaruh ideal yaitu mampu meyakinkan, mendaramatisasikan misi dan merespons visi organisasi dalam program dan kegiatan, inisiatif sebagai strategi perubahan, mempromosikan inovasi dalam produk dan teknologi. Pemimpin visioner memiliki karakteristik transformasional yaitu mampu mendorong anggota untuk peduli, mampu menstimulasi satu sama lain secara intelektual, menginspirasikan satu sama lain, dan mengidentifikasikan dengan sasaran yang senantiasa berprestasi tinggi (Sagala S. , 2016). 2018)

Kepemimpinan bermoral dan visioner memiliki ciri-ciri sebagai berikut: (Sagala S.,

1. Pemimpin itu memahami berbagai segi kegiatan organisasi secara tepat menggunakan daya kognitif dan daya nalar secara teratur dan intensif;

2. Responsif terhadap perubahan IPTEK;

3. Memiliki keterampilan (skill) berkomunikasi secara efektif;

4. Melihat kepentingan organisasi sebagai keseluruhan di atas segalanya;

5. Berpikir dan betindak objektif dan rasional;

6. Tajam dalam menentukan prioritas. 
Dapat ditegaskan bahwa pemimpin visioner, mampu mengondisikan misi organisasi konsisten dengan nilai-nilai yang dianut organisasi. Seni memimpin juga menggambarkan kualitas manajemen perubahan yang ditampakkan pada integritas, nilai dan kecakapan interpersonal pemimpin visioner terlihat pada kemampuannya (Sagala S. , 2018):

1) Memberi support dan tidak menjatuhkan orang;

2) Memperlakukan staf secara setara dan mendengarkan secara saksama, memberikan kesempatan kepada siapa saja dalam mengutarakan pendapatnya

3) Teratur dan efisien tetapi tidak berlebihan dengan efisiensi;

4) Peduli dan antusias pada visi dan misi organisasi;

5) Memiliki rasa humor;

6) Beretika tinggi dan dapat dipercaya serta dapat menerima perbedaan membingungkan;

7) Berkomiten dalam menyelesaikan kegiatan dengan baik;

8) Bertindak tenang dan sesuai koridornya bila terjadi kesalahan;

9) Mau mencoba dan mengambil risiko dan belajar dari kesalahan;

10) Tidak hanya sekedar bekerja tetapi memiliki ketertarikan yang lebih luas;

11) Berani menerima sesuatu yang terjadi;

12) Berkomitmen dan berorientasi pada aksi untuk memimpin dengan memberi teladan.

\section{METODOLOGI PENELITIAN}

\section{Metode penelitian}

Metode yang digunakan yaitu kualitatif atau yang disebut juga dengan penelitian alamiah yang memiliki menghasilkan data deskriptif berupa tulisan atau ucapan dan perilaku orang-orang yang diamati. dari suatu individu, kelompok, masyarakat atau organisasi tertentu yang dikaji dari sudut pandang komprehensif, utuh dan holistik (Tersiana, 2018). Penelitian ini berusaha untuk mencari gambaran/deskripsi mengenai bagaimana model kepemimpinan visioner pada Yayasan Sasmita Jaya Group di Provinsi Banten.

\section{Populasi dan Sampel}

Penelitian ini tidak mengutamakan besarnya populasi dan sampel, artinya sampel boleh jadi sangat terbatas. Teknik pusposive sampling menjadi teknik pilihan dalam menetapkan informan, dengan tujuan yaitu agar perolehan data sesuai dengan kebutuhan. Teknik yang merupakan teknik penentuan informan dengan berbagai pertimbangan untuk memperoleh informasi yang diperlukan. Subyek yang dipilih yang paling penting dan tahu sesuai dengan yang diharapkan merupakan pertimbangan yang peneliti gunakan dalam penelitian ini (Sugiyono, 2012). Sedangkan sampel penelitian kualitatif dapat sebagai nara sumber, partisipan atau informan, yaitu Ketua Yayasan Sasmita Jaya Group dan salah satu pegawai yang sudah lama bekerja di Yayasan Sasmita Jaya Group bagian kepegawaian.

\section{Teknik Pengumpulan Data}

Teknik pengumpulan data yang peneliti gunakan untuk menjawab permasalahan penelitian dengan menggunakan observasi, wawancara dan dokumentasi. Untuk keabsahan data digunakan triangulasi sumber yaitu penggalian kebenaran melalui berbagai cara dan sumber perolehan data (Moleoang, 2011). Uji keakurasian data dilakukan dengan croscek data dari sumber data yang berbeda. Selanjutnya data diidentifikasi, dikategorikan, direduksi dan ditarik kesimpulan.

\section{Instrumen Pengumpulan Data}


Data yang digunakan dalam penelitian ini terdiri dari data primer dan data sekunder.

a. Data primer yang digunakan dalam penelitian ini yaitu observasi dan wawancara. Responden dalam penelitian ini merupakan pemimpin Yayasan Sasmita Jaya Group dan beberapa pegawai.

b. Data sekunder dalam penelitian ini menggunakan kepustakaan, jurnal, foto, dokumen, dan catatan lapangan.

\section{Teknik Analisis Data}

Analisis data diperoleh setelah melakukan observasi, wawancara dan beberapa data sekunder lainnya. setelah itu dilakukan Reduksi Data (Data Reduction), Paparan Data (Data Display), Penarikan Kesimpulan Data dan Verifikasi (Conclusion Drown/ Verification). (Sugiyono, 2012).

\section{HASIL DAN PEMBAHASAN}

\section{Hasil Penelitian}

Peneliti melakukan penelitian ini dengan menggunakan teknik observasi dan wawancara dengan menggunakan metode penelitian kualitatif. Observasi dan wawancara yang telah kami lakukan dilaksanakan di Universitas Pamulang, Jalan Surya Kencana No. 1 Pamulang Tangerang Selatan Banten. Pada tanggal 31 Juli 2020 pada pukul 09.00 s.d selesai dan beberapa bulan sebelumnya dengan pegawai serta Ketua Yayasan langsung.

Selain itu, kami juga menggunakan data sekunder dari data-data yang kami cari melalui artikel terkait tentang Yayasan Sasmita Jaya Group. Dari hasil data yang kami peroleh baik data primer dan sekunder mengenai profil singkat bapak Dr. (HC). $\mathrm{H}$. Darsono lahir di Yogyakarta tanggal 5 Juli 1955, putra keempat dari Bapak Ahmad Hudori dan Ibu Siti Badriah. Bapak Dr. (HC) H. Darsono alumnus Institut Keguruan dan IImu Pendidikan (IKIP) Yogyakarta yang sekarang bernama Universitas Negeri Yogyakarta (UNY) dari Fakultas Ekonomi lulus tahun 1982. Menikah pada tanggal 21 Januari 1984 dengan Ibu Dra. Hj. Ika Pudji Mediana dengan dikarunia dua orang anak yaitu Dr. Pranoto, S.E., M.M., dan dr. Safitri.

Pada tahun 1989 bersama istrinya mendirikan Yayasan Sasmita Jaya Group yang hingga kini sebagai Ketua Yayasan. Yayasan ini memiliki Sekolah Menengah Kejuruan (SMK) Sasmita Jaya 1, SMK Sasmita Jaya 2, Universitas Pamulang, STIKES, Klinik EDH dan beberapa bisnis lainnya yaitu Pabrik Tahu, Peternakan, Perkebunan, Pertanian, Properti serta PT BPR (Bank). Pada tahun 2005 beliau mengakuisisi Yayasan Prima Jaya yang menaungi Universitas Pamulang yang berdiri dari tahun 2000 diketuai oleh Drs. Wayan. Hal ini dikarena ketidakmampuan Yayasan tersebut dalam mengelola suatu universitas, maka Universitas Pamulang dialihkan kepemilikan dan pengelolaannya kepada Yayasan Sasmita Jaya (Pamulang, 2020). Selain itu, pada tahun 2020 Yayasan Sasmita Jaya Group juga mengakuisis Yayasan Widiya Dharma Husada yang menaungi Sekolah Tinggi Ilmu Kesehatna dan Klink Widiya Dharma Husada yang berletak di Jalan Surya Kencana Pamulang Tangerang Selatan.

Berdasarkan hasil wawancara dengan responden dapat diketahui bahwa pemimpin Yayasan Sasmita Jaya Group memiliki model kepemimpinan visioner. Bapak Dr. (HC). H. Darsono merupakan lulusan Fakultas Ekonomi Universitas Negeri Yogyakarta (UNY) yang memiliki visi masa depan memberikan yang terbaik untuk bumi pertiwi dengan 
kemampuan, skill, ilmu yang dia dapatkan dari kecil di pedesaan hingga hijrah ke kota Pamulang.

Sebelum tinggal di Pamulang, $\mathrm{Pa}$ Dar menempati rumah keluarga sederhana yang memiliki 11 anak dengan berjualan daun dan lain-lain di pasar. Pa Dar menumpang tinggal di rumah sederhana tersebut dan bekerja sehari-hari dengan penuh keperihatinan dan bekerja keras untuk mewujudkan cita-citanya yang ingin berbagi kepada sesama yang membutuhkan.

Sebelum bergelut di dunia bisnis, Bapak Dr. (HC). H. Darsono yang akrab dipanggil Pa Dar bekerja sebagai Pegawai Negeri Sipil (PNS), karena dahulu menjadi PNS merupakan pekerjaan yang sangat diminati oleh para lulusan dari perguruan tinggi swasta maupun negeri. Setelah tiga tahun bekerja di PNS merasa bahwa visinya untuk berbagi kepada orang-orang yang membutuhkan sangat sulit dilakukan karena harus terikat oleh waktu yang sudah ditentukan selama delapan jam di kantor pemerintahan. Oleh karena itu, Pa Dar berhenti kerja dari PNS nya dan berusaha menjalankan bisnis sesuai dengan kemampuan, skill dan ilmu yang dimiliki dengan menjadi guru, usaha pertanian, peternakan, pabrik tahu dan properti perumahan di daerah Pamulang Tangerang Selatan dan Serang Banten.

Bisnis itu semua dijalankan sesuai dengan kebutuhan para pegawai atau anggota di bawahnya, supaya mereka memiliki komitmen, loyalitas yang tinggi serta memberikan yang terbaik untuk Yayasan Sasmita Jaya Group. Salah satu yang dilakukan Pa Dar yaitu dengan memberikan fasilitas perumahan dengan harga yang terjangkau dan dekat dengan sekolah atau tempat usaha yang dijalaninya. Sehingga meminimalisir kekurangan dalam biaya hidup keluarga karyawan dan mengurangi biaya transportasi. Hal ini dilakukan tidak lain untuk memberikan yang terbaik untuk para pegawainya yang telah bekerja dengan penuh semangat, hati dan maksimal untuk mencapai hasil yang optimal.

\section{Pembahasan}

Setelah melakukan observasi dan wawancara langsung dengan pemimpin Yayasan Sasmita Jaya Group yaitu Bapak Dr. (HC). H. Darsono pada tanggal 31 Juli 2020 di kampus Universitas Pamulang pukul 09.00 sd selesai maka peneliti dapat mendeskripsikan hasil wawancara tentang Model Kepemimpinan Visioner Yayasan Sasmita Jaya. Dalam hal ini, pak H. Darsono memiliki keunikan model kepemimpinannya sehingga dapat membesarkan nama Universitas Pamulang di tengah masyarakat luas di provinsi Banten. Kepemimpinan visioner pak H. Darsono dapat membantu masyarakat terbelakang secara ekonomi dan Pendidikan di berbagai tempat. Masyarakat yang terbelakang kehidupannya disulap menjadi masyarakat terdepan secara ekonomi dan Pendidikan. Tentu untuk mengubahnya tidak semudah membalikan telapak tangan.

\section{Model Kepemimpinan Visioner pada Yayasan Sasmita Jaya}

Model kepemimpinan visioner Yayasan Sasmita Jaya Group memiliki perpaduan dengan visioner menurut beberapa ahli. Dari hasil wawancara dan observasi yang peneliti lakukan dapat diketahui model kepemimpinan visioner Yayasan Sasmita Jaya Group yang ada di dalam diri Bapak Dr. (HC) H. Darsonoso sebagai berikut: 


\section{Ruh Berbagi}

Rahasia kepemimpinan visioner pak H. Darsono adalah memiliki keunikan tersendiri. Keunikan model kepemimpinannya adalah ia ingin membangun "ruh berbagi". Itu modal dasar yang dimiliki pak $\mathrm{H}$. Darsono sebelum sukses membangun UNPAM. Tidak mudah menanamkan ruh berbagi di dalam mental orang-orang. Sebagian orang melupakan unsur-unsur tersebut pada saat mulai sukses. Di Indonesia banyak lembaga pendidikan seperti sekolah dan perguruan tinggi membawa bendera agama akan tetapi tidak memiliki ruh berbagi, kering dan hampa. Banyak lembaga-lembaga Pendidikan yang tidak mencapai tujuan sebenarnya yaitu Tahdziibul Akhlaq (Penanaman Akhlaq) namun yang didapat anak didik hanyalah "profit oriented not people oriented". Yang boleh sekolah hanyalah orang-orang kaya, anak-anak pejabat, pengusaha, artis sedangkan orang-orang miskin yang tidak punya biaya tidak diterima di sekolah. Suatu hal yang sangat ironis jika sebuah Pendidikan hanya mengejar keuntungan saja tanpa mempertimbangkan kecerdasan otak dan kecerdasan mental anak. Pendidikan yang sangat mahal dan berorientasi hanya keuntungan saja akan menimbulkan penyakit social di masyarakat yaitu ; Orang kaya hanya bergaul dengan sekelasnya, Yang berhak pintar hanyalah orang-orang kaya, yang berhak mendapatkan pekerjaan enak dengan gaji besar hanyalah orang-orang kaya. yang berhak memimpin hanyalah orang-orang kaya, dan yang berhak mengubah hidup orang lain adalah orang-orang kaya. Keuntungan-keuntungan yang telah menyimpang dari tujuan akhir Pendidikan digunakan sebagai dasar visi dan misi membangun sekolah dan perguruan tinggi. Lebih celaka lagi sebagiannya mengejar keuntungan seperti mengejar Tuhan sehingga menghalalkan berbagai macam cara. Apabila semua Pendidikan dibangun hanya berlandaskan keuntungan dan mengambil keuntungan semata maka akan melahirkan generasi-genarasi yang terbelakang secara mental dan moral. Lembaga Pendidikan yang tidak memiliki ruh berbagi maka Lembaga Pendidikan tersebut tidak punya wibawa dan harga diri. Pak $\mathrm{H}$. Darsono membawa konsep "ruh berbagi" dalam setiap usahannya sehingga orang-orang miskin mendapatkan kesempatan sekolah dan bekerja. Pak H. Darsono hadir melalui Unpam, ingin menjernihkan mindset yang keliru tentang tujuan akhir Pendidikan. Pentolan Yayasan Sasmita Jaya, Pak H. Darsono menerapkan konsep berbagi kepada orang-orang dhuafa melalui usaha yang dikembangkan. Keunikan yang dimiliki pak $\mathrm{H}$. Darsono meniru sifat-sifat Nabi saw yaitu Fathonah (cerdas) dan Amanah (Dapat dipercaya). Untuk membangun ruh berbagi dapat dimulai dari kecerdasan. Seberapa cerdas seorang pemimpin mengelola karyawan dan mengembangkan usahannya. Seberapa besar amanah yang sedang dijalankan. Pak $\mathrm{H}$. Darsono adalah orang yang memiliki komitmen tinggi dan amanah dalam menjalankan tugasnya. Pemimpin yang sudah memiliki "ruh berbagi" sangat peduli kepada orang miskin. Konsep ruh berbagi sangat humanis dan tidak bertentangan dengan ajaran agama dan akal sehat. Artinya habit ini, sangat diterima oleh agama dan akal sehat. Secara agama mengajarkan bahwa Tuhan memiliki sifat berbagi karenanya Tuhan memiliki sifat Pengasih kepada makhlukNya. Tuhan memerintahkan kepada manusia untuk saling berbagi. Karenanya berbagi menjadi 
sifat dasar sesama manusia. Kemudian secara akal sehat "ruh berbagi" sangat humanis. Artinya semua manusia memiliki sifat dasar untuk saling berbagi. Akal sehat manusia yang mendorong itu semua. Manusia diciptakan Tuhan sebagai makhluk sosial sehingga memiliki jiwa sosial. Manusia yang tidak pernah berbagi maka tidak dapat bertahan hidup lebih lama. Konsep "ruh berbagi" sangat menguntungkan semuanya sehingga dapat bertahan hidup. Ajaran Islam mengajarkan pengikutnya saling berbagi. Aktivitas saling berbagi dapat dilakukan setahun sekali disebut dengan Zakat dan Qurban dan rutin setiap waktu disebut dengan infaq dan sodaqoh. Ajaran Islam menjunjung tinggi nilai-nilai kemanusiaan. Pak $\mathrm{H}$. Darsono memiliki sifat kemanusiaan yang tinggi dan tingkat ketaatan yang yang baik karena telah menjalankan perintah Allah serta ajaran Nabi saw. Karenanya sosok kepemimpinannya perlu menjaadi inspirasi bagi pemimpin yang lain.

\section{Empati}

Kepemimpinan visoner pak $\mathrm{H}$. Darsono memiliki rasa empati. Menurutnya, kita hidup mesti empati terhadap orang susah, sebab mereka yang layak dibantu bukan orang yang sudah mapan maupun kaya. Banyak orang di sekitar kita yang susah secara ekonomi sehingga mereka sulit memenuhi kebutuhannya sendiri. Tentunya kondisi ekonomi mereka yang sulit akan berdampak terhadap tingkat Pendidikan mereka. Dengan biaya Pendidikan yang sekarang mahal di Indonesia maka mereka yang bekerja sebagai tukang cuci, buruh kasar, dan pemulung sulit duduk di bangku sekolah. Apalagi selama masa pandemik ini banyak pekerja-pekerja yang dirumahkan seperti karyawan restoran, buruh pabrik, dan sebagainya. Sehingga di Indonesia Pendidikan hanya dinikmati oleh orang-orang yang kaya dan yang pintar hanya orang-orang yang berduit. Tentu saja orang kaya itu menjadi pintar sebab mereka bisa menikmati semua fasilitas Pendidikan sedangkan orang-orang miskin semuanya serba terbatas karena kondisi ekonomi yang sulit membatasi itu. Sebagian orang-orang miskin banyak juga yang pintar dan mampu meraih sukses asalkan diberikan peluang bersekolah hingga perguruan tinggi. Di sini Unpam (Universitas Pamulang) memberikan terobosan baru di tengah mahalnya biaya Pendidikan di Indonesia. Unpam hadir di tengah masyarakat dengan memberikan peluang kepada masyarakat miskin menerima pendaftaran mahasiswa dengan biaya sangat murah. Kalau biaya kuliah di kampus lain persemester sebesar 6 juta sedangkan Unpam biaya kuliah hanya 6 ratus ribu dan jika dicicil perbulannya biaya kuliah hanya 100 ribu rupiah. Dengan biaya kuliah murah maka semua orang-orang miskin yang berprofesi sebagai pekerja kasar dan pekerja serabutan bisa kuliah di Unpam.

Selain masyarakat sekitar, sebagai pentolan UNPAM, Pak $H$. Darsono menyampaikan rasa empatinya juga terhadap karyawan Universitas pamulang yang bekerja. Menurutnya, rasa empati itu penting dilakukan karena hal ini akan mempengaruhi terhadap profesionalitas kerja dan loyalitas karyawan. Rasa empati yang dilakukan adalah dengan memberikan akses para karyawan melanjutkan studi di UNPAM dan memberikan kesempatan Pendidikan di luar. Selain itu, diberikan fasilitas perumahan dengan harga yang terjangkau sehingga memudahkan mereka 
bekerja dengan jarak yang tidak jauh dengan rumah mereka. Apabila karyawan memiliki rumah pasti mereka menjadi lebih nyaman dan aman dalam bekerja.

\section{Sederhana dan Rendah Hati}

Sebagai pimpinan Yayasan Sasmita Jaya Group, Pak Dar yang saat ini bisa disebut "Milyader", tetap menunjukkan kesederhanaan dalam kesehariannya. la menunjukkan sikap sederhana bertemu dengan siapapun termasuk dalam berpenampilan, tidak glamour. Sebagai seorang pimpinan, la memiliki ruangan kerja pribadi dengan fasilitas sederhana dan tidak ada barang-barang mewah yang dipajang di ruangannya. Setiap ia diundang memberikan sambutan acara kampus menunjukkan gaya yang sederhana, menyampaikan isi sambutan yang sederhana dengan arti la menyampaikan sesuatu sesuai dengan fakta dan pesan-pesan yang beliau sampaikan memberikan pencerahan kepada staff, dosen, karyawan, dan juga mahasiswa tentang ilmu berbagi kepada sesama. Pak Darsono dalam situasi lain menunjukkan sikap humble (rendah hati) kepada siapapun. Sebagai orang yang nomor satu di Yayasan Sasmita Jaya Unpam, la senantiasa memberikan pembinaan kepada bawahannya dan mahasiswa. Pembinaan yang sangat menarik dan memberikan manfaat kepada masyarakat luas. Binaan yang berisi pesan-pesan humanis yaitu "indahnya berbagi". Berbagi kepada siapapun khususnya kepada kaum dhuafa atau orang-orang miskin yang sulit makan dan memenuhi kebutuhan sehari-hari. Konsep "ruh berbagi" menjadi sebuah icon kesuksesannya di berbagai sector. Pak Darsono, telah menunjukkan keunikan leadershipnya sehingga ia sukses membangun kampus Universitas Pamulang. Pak Darsono yang sederhana dan humble menyembunyikan rahasia kesuksesannya dibidang Pendidikan. Sikap rendah hati lain yang ia tunjukkan adalah selalu belajar kepada siapapun. la terbuka mau menerima masukan dan saran yang membangun dari siapapun. Sekalipun beliau memiliki saran yang lebih baik dari yang memberi saran namun beliau tidak show off, merasa lebih pintar, lebih hebat, lebih bersih, dan apalagi merasa lebih kaya. Banyak orang-orang menengah ke bawah yang tidak mampu secara financial dapat melanjutkan kuliah di Universitas Pamulang dengan biaya kuliah murah.

\section{Kreatif}

Selain memiliki empati, sederhana, dan rendah hati, la juga memiliki pemikiran kreatif. Menciptakan inovasi pemikiran di bidang ekonomi dan Pendidikan. la bukan pakar Pendidikan dan pakar ekonomi namun ia kreatif membangun perubahan hidup khalayak orang banyak. Semua jenis usaha yang ia pimpin berjalan dengan lancar dan sukses oleh karena inovasi management yang ia terapkan. Dalam pemikirannya bahwa sebuah usaha tidak akan collapse (runtuh) jika management keuangannya sehat. Jelaslah manajemen keuangan Universitas Pamulang yang baik akan mempengaruhi kemajuan kampus Unpam. Dalam hal ini, dalam sebuah perusahaan manajemen keuangan ibarat mesin sebuah kendaraan. Jika mesin sebuah kendaraan sudah rusak dan tidak berfungsi maka kendaraan akan stuck sehingga tidak akan mencapai tujuan perjalanan. Agar tidak rusak mesin suatu kendaraan mesti rutin diservis. Demikian halnya dengan manajemen keuangan mesti dikontrol 
dan diberikan training-training SDM secara intens sehingga menajemen keuangan akan lebih rapih dan organize. Pelaku SDM keuangan yang sudah tidak layak lagi secara moralitas artinya tidak jujur maka harus diganti dengan pelaku yang yang layak secara moralitas. Pekerja yang pemalas dan tidak jujur selalu menjadi bom waktu dalam pengelolaaan keuangan. Sirkulasi keuangan akan terhambat karena di internal bagian keuangan tidak disiplin dan banyak kebohongan sampai rusaknya kepercayaan satu sama lain. Rusak kepercayaan tersebut akan berpengaruh terhadap profesionalitas manajemen sehingga manajemen menjadi lumpuh. Manajemen keuangan yang sudah rusak akan berdampak terhadap kerugian gaji karyawan dan bahkan kerugian perusahaan. Perusahaan yang hendak bangkrut akan berupaya melakukan langkah-langkah yang tidak sehat seperti pengurangan karyawan perusahaan atau PHK besar-besaran dan menjual aset perusahaan. Spekulasi-spekulasi tersebut yang membuat model kepemimpinan Yayasan Sasmita Jaya menjadi lebih kreatif dan inovatif sehingga mampu mengatasi resiko-resiko yang akan terjadi di kemudian hari. Selain manajemen keuangan, Pak $\mathrm{H}$. Darsono juga memperhatikan kesejahteraan karyawan yang lainnya. Menurutnya, karyawan mesti diperhatikan kesejahteraannya agar mereka senang sehingga bisa bekerja dengan hati. Kesejahteraan yang dimaksud adalah memudahkan akses mereka untuk berkarya. Karyawan diberikan kesempatan untuk kuliah di Unpam, semua Dosen Unpam dibantu untuk melakukan penelitian dan sertifikasi dosen sehingga para dosen memiliki pemasukan bulan tidak hanya di Unpam tetapi juga dari Kemenristek Dikti. Dosen yang banyak meneliti dan serdos akan meningkatkan prestasi Unpam di kancah Nasional. Peringkat Universitas Pamulang akan meningkat naik dari tahun ke tahun melalui prestasi-prestasi tersebut. Selain itu, Pak H. Darsono juga sudah menfasilitasi perumahan untuk dosen dan karyawan Unpam dengan biaya murah dan lokasinya dekat Unpam sehingga mereka tidak perlu ngontrak bulanan dan tahunan dan juga bisa lebih efisien sampai Unpam. Ide-ide kreatif tersebut menguntungkan orang banyak sebagaimana dalam sebuah hadits Nabi Muhamamd SAW, "Manusia yang terbaik adalah manusia yang banyak memberikan manfaat kepada orang lain". Pak H. Darsono telah memberikan manfaat yang banyak kepada orang-orang miskin tanpa memandang latar belakang budaya, ras, dan kepercayaan apapun.

\section{Berjiwa Usahawan}

Model kepemimpin pak $\mathrm{H}$. Darsono yang adalah memiliki jiwa usahawan atau entrepreneurship. Untuk membangun Gedung Unpam dan Fasilitas lain dengan megah, Pak H. Darsono tidak membangunnya dengan sistem cashflow yaitu bergantug pendapatan biaya kuliah mahasiswa yang masuk, berapa cost yang dikeluarkan Unpam, dan berapa laba yang didapat. Kalau bangun Gedung hanya bergantung pendapatan cashflow maka secara logika ekonomi tidak akan cukup. Biaya kuliah Unpam sangat murah dan mahasiswa tidak dikenakan biaya Gedung. Biaya kuliah sampai saat ini di Unpam persemester 600 ribu rupiah dan boleh dicicil perbulan sebesar 100 ribu rupiah. Biaya kuliah yang sangat ekonomis bila dibandingkan kampus lain biaya persemester sebesar 6 juta rupiah. Dikarenakan paling murah biaya kuliah di Unpam maka membuat penasaran seorang tokoh ICMI, 
Prof. Jimmy As Shidiqy, yang juga memiliki kampus di Bali sehingga akhirnya datang berkunjung ke kampus Universitas Pamulang untuk melihat Gedung Unpam yang besar dan megah. Tujuan pertemuan tokoh tersebut yaitu ingin mengetahui rahasia sukses pak Dr. (HC) H. Darsono membangun megah Gedung Unpam dengan biaya murah. Pertemuan tersebut disambut baik oleh ketua Yayasan Sasmita Jaya dan ia kemudian saling sharing ide dan pengetahuan. Menurut pak $\mathrm{H}$. Darsono, untuk membangun Gedung megah Unpam ia membuka kran-kran yang lain. Kran-kran yang bisa memberikan manfaat banyak orang. Banyak orang-orang miskin dapat diringankan secara ekonomi dengan dibukannya kran-kran itu dan dengan usaha keras dan keringat orang miskin juga para mahasiswa dan dosen dapat menikmati fasilitas Gedung kuliah yang nyaman. Kran-kran yang dimaksud adalah Usaha lain. Pak H. Darsono memiliki keahlian di bidang arsitek. Menurutnya, gedung Unpam yang dibangun ia design sendiri sehingga terlihat bagus. Selain arsitek, pak $\mathrm{H}$. Darsono membuka usaha di bidang pertanian. Dalam membuka usaha ini, ia tidak hanya investor/pemodal usaha namun ia pandai dalam mengelola pertanian. Pertanian yang sudah berkembang yaitu beras Unpam. Produk ini sekarang dijual di kopinmart Universitas Pamulang. la juga pemodal usaha peternakan sapi dan kambing. Selain investor ia juga terjun mengelola perternakan. Setiap tahun sekitar 300 ekor ternaknya diqurbankan pada waktu hari raya Idul Adha. la juga membuka usaha bengkel. Dalam usaha ini ia sebagai pemodal usaha. Usaha lain yang ia bangun adalah Bank Darsono. Usaha ini sudah berjalan di Tangerang dan rencananya akan dipindahkan di Universitas Pamulang Viktor. Bank Darsono akan membantu semua nasabahnya karena nasabah yang meminjam di Bank Darsono akan dikenakan potongan bunga hanya $8 \%$. Jauh lebih kecil potongan bunganya dibandingkan bank-bank konvensional lainnya yang mengambil potongan pinjaman dengan bunga $10 \%$. Semua orang yang bekerja di usaha pak H. Darsono adalah orang yang tinggal di sekitar tempat usahanya sehingga mudah dijangkau semuanya. Seperti misalnya usaha pertanian dan perternakan yang dibuka di Serang Banten maka pekerjanya orang Serang yang tinggal dekat lokasi usaha.

Demikianlah model kepemimpinan Yayasan Sasmita Jaya yang dapat menginspirasi banyak orang khususnya di Dunia Akademisi. Sehingga ia pantas mendapatkan penghargaan keilmuan dengan gelar Dr. Honoris Causa (HC) dari Universitas Negeri Yogyakarta semua ide dan usahanya dapat dibuktikan secara ilmiah. Dari analisis tersebut, maka dapat dijelaskan dengan ringkas melalui tabel berikut ini :

\begin{tabular}{|l|l|}
\multicolumn{3}{|c|}{ Model Kepemimpinan Visioner Ketua Yayasan Sasmita Jaya } \\
Provinsi Banten
\end{tabular}




\section{E. KESIMPULAN}

Yayasan Sasmita jaya semakin eksis disebabkan kepemimpinan visioner pak $\mathrm{H}$. Darsono. Kepemimpinan visioner pak $\mathrm{H}$. Darsono yang paling esensial adalah memiliki konsep "ruh berbagi". Konsep tersebut sudah diterapkan lama sejak ia belum membangun usaha lainnya. Bahkan konsep tersebut sudah menjadi habit di masa muda beliau. Konsep tersebut memiliki aspek humanis yang tinggi sehingga tidak melanggar ajaran agama. Islam sangat menganjurkan pengikutnya untuk menerapkan habit tersebut dalam kehidupannya.

Model kepemimpinan pak Dr. (HC) H. Darsono memiliki beberapa karakteristik yaitu ruh berbagi, empati, sederhana, rendah hati, kreatif, dan entrepreneurship. Tipikal tersebut yang membuat pak $\mathrm{H}$. Darsono sukses dalam membangun UNPAM dan usaha lainnya. Dengan model kepemimpinan tersebut, pak $\mathrm{H}$. Darsono memiliki komitmen tinggi dan professional dalam menjalankan tugas. Dengan model itu pula, la dapat berlaku adil dalam mengambil keputusan.

\section{DAFTAR PUSTAKA}

Amram, J. Y. (2009). The Contribution of Emotional and Spiritual Intelligences to Effective Business Leadership. California: Dissertation of Psychology of Institute of Transpersonal Psychology.

Bachrun, S. (2014). Buku Induk Manajemen SDM-Human Capital Syariah. Bekasi: LAZIS Dewan Da'wah Islamiyah Indonesia.

Badaruzaman, B. (2014). Brain Genetic Potential. Bandung: Mizania.

Bateman, T. S., \& Scott A. Snell. (2014). Manajemen Kepemimpinan dan Kerja Sama dalam Dunia yang Kompetitif. Jakarta: Salemba Empat.

Carnegie, D. (2009). Leadership Mastery Sukses Memimpin Diri Sendiri dan Orang Lain Meraih Posisi \#1. Jakarta: PT Gramedi Pustaka Utama.

Choiriah, A. ( 2013). Pengaruh Kecerdasan Emosional, Kecerdasan Intelektual,Kecerdasan Spiritual, dan Etika Profesi terhadap Kinerja Auditor dalam Kantor Akuntan Publik. Padang: Fakultas Ekonomi Universitas Negeri Padang.

Crow, L. D. (1984). Educational Psychology, terj. Z. Kasijan Psikologi Pendidikan. Surabaya: Bina IImu.

Dwijayanti, A. P. (2009). Pengaruh Kecerdasan Emosional, Kecerdasan Intelektual, Kecerdasan Spiritual dan Kecerdasan Sosial terhadap Pemahaman Akuntansi. Jakarta: Universitas Pembangunan Nasional "Veteran".

Dwijayanti. (2009). Pengaruh Kecerdasan Emosional, Kecerdasan Intelektual, Kecerdasan Spiritual dan Kecerdasan Sosial terhadap Pemahaman Akuntansi. Jakarta: Universitas Pembangunan Nasional "Veteran". 
Farida, S. I. (2018). Anggaran responsif gender sebagai suatu instrumen negara untuk pemenuhan hak perempuan di Indonesia. JIMF (Jurnal IImiah Manajemen Forkamma), 1(2).

Farida, S. I., \& Anjani, S. R. (2019). Menumbuhkan Jiwa Kepemimpinan pada Mahasiswa di Lingkungan Universitas Pamulang. INOVASI, 6, 1-20.

Farida, S. I., \& Anjani, S. R. (2019). Menumbuhkan Jiwa Kepemimpinan Pada Mahasiswa di Lingkungan Universitas Pamulang. INOVASI, 6(2), 19-20.

Farida, S. I., \& Fauzi, M. M. (2020). Pengaruh Gaya Kepemimpinan Terhadap Kinerja Karyawan Pada Pt Sarimelati Kencana Pizza Hut Delivery Cabang Ciputat. Jurnal Al Azhar Indonesia Seri IImu Sosial, 1(2), 63-73.

Farida, S. I., \& Khair, O. I. (2019). Leadership sebagai Dasar Kecerdasan Intelektual Mahasiswa Program Studi Manajemen di Universitas Pamulang. FORKAMMA, 3, 46-60.

Farida, S. I., Iqbal, M., \& Kurniasih, A. (2016). Pengaruh Kepercayaan Dan Komitmen Organisasi Terhadap Motivasi Kerja Serta Implikasinya Pada Kepuasan Kerja. Jurnal Kependidikan: Penelitian Inovasi Pembelajaran, 46(1), 121-134.

Farida, S. I., Prasetiyani, D., Safiih, A. R., Prasada, D., \& Ismanto, B. (2020). Pelatihan SDM: Usaha Konvensional menjadi Usaha Digital. Jurnal Abdi Masyarakat Humanis, 1(2).

Goleman, D. (1998). Emotional Intelegence, terj. T. Hermaya, Kecerdasan Emosional. Jakarta: Gramedia.

Hauen, F. V. (2015). The Power of Leadership: Mentransformasi Nilai-Nilai Menjadi Tindakan dengan Mereorganisasi Pengawasan. Yogyakarta: Amara Books.

Hersugondo, E. S. (2008). Kepemimpinan yang Efektif dan Perubahan Organisasi. Fokus Ekonomi, 85.

Hidayat, R., \& Wijaya, C. (2017). Ayat-ayat Al-qur'an tentang Manajemen Pendidikan Islam. Medan: Lembaga Peduli Pengembangan Pendidikan Indonesia (LPPPI) Press.

Indraini, A. (2020, Juni 29). https://finance.detik.com/berita-ekonomi-bisnis/d5073093/sudah-6-juta-warga-ri-kena-phk-dan-dirumahkan/2. Retrieved from detik.com: https://finance.detik.com/berita-ekonomi-bisnis/d-5073093/sudah-6-jutawarga-ri-kena-phk-dan-dirumahkan/2

Isabela. (2011). Pengaruh Kecerdasan Emosional, Kecerdasan Spiritual, dan Kecerdasan Intelektual terhadap Kinerja Auditor dalam Kantor Akuntan Publik. Semarang: Universitas Khatolik Soegijapranata Semarang.

Lativa, L., Sanjaya, R., Farida, S. I., Al Choir, F., \& Sunardi, D. (2020). PELATIHAN PERHITUNGAN PAJAK PPH PASAL 21, PASAL 23, DAN PPH PASAL 4 AYAT 2 

TANGERANG SELATAN GUGUS 02. DEDIKASI PKM, 1(1), 80-85.

Lesmana, R., Sunardi, N., Kartono, K., Rudy, R., \& Sumiaty, R. Y. (2020). Implementasi Manajemen dalam Meningkatkan Minat Baca Warga Desa Cihambulu, Kec. Pabuaran, Kab. Subang, Jawa Barat. Jurnal Abdi Masyarakat Humanis, 1(2).

Manulang, B. (1999). Kecerdasan Emosional Aplikasi dalam Pembelajaran, dan Kayu Duha, Kecerdasan Emosional: Aplikasi dalam Pendidikan. Kecerdasan Emosional dan Aplikasinya di Dalam Pembelajaran, Fakultas IImu Pendidikan IKIP Medan. Medan: IKIP Medan.

Ma'sum, T. (2019). Persinggungan Kepemimpinan Transformational dengan Kepemimpinan Visioner dan Situasional. INTIZAM: Jurnal Manajemen Pendidikan Islam, 84-106.

Matondang. (2008). Kepemimpinan Budaya Organisasi dan Manajemen Strategik. Yogyakarta: Graha IImu.

Mediani, M. (2019, Agustus 2). cnnindonesia.com. (CNN Indonesia) Retrieved Agustus 15, 2019, from https://www.cnnindonesia.com/nasional/20190802172238-20417874/130-perguruan-tinggi-swasta-ditutup-sepanjang-2015-2019

Moeljono, D. (2017). 13 Konsep Beyond Leadership. Jakarta: Elex Media Komputindo.

Moleoang, L. J. (2011). Metodologi Penelitian Kualitatif. Bandung: PT Remaja Rosdaharya.

Nielsen, D. R. (1982). Educational Psychology The Development of Teaching Skills. New York: Harper 7 Row.

pamulang, u. (2020). http://unpam.ac.id/sejarah/. Retrieved from http://unpam.ac.id/sejarah/

Prastiwi, D. (2019, Februari 11). merdeka.com. (Merdeka) Retrieved Agustus 14, 2019, from liputan6.com: https://www.merdeka.com/peristiwa/mendikbud-akui-wajibbelajar-12-tahun-belum-maksimal.html

Raharjo, N. E., \& Usman, H. (2013). Strategi Kepemimpinan Pembelajaran Menyongsong Implementasi Kurikulum 2013. Cakrawala Pendidikan, 1-13.

Rivale, W. (2011). Faktor Intelektual yang Menentukan Kepribadian. Jurnal Pendidikan Sosiologi dan Humaniora, Vol. 2, No. 1, April, 62-73.

Rovita, A., Farida, S. I., Surasni, S., Yuwono, T., \& Sumali, A. (2020). MENGAJAR DENGAN METODE MOTIMORFOSIS. DEDIKASI PKM, 1(1), 48-52.

Sagala, S. (2016). Headmaster's Transformative Leadership Resulting in Quality Performance. The First Annual International SEminar on Transformatif Education and Educational Leadership. Medan. 
Sagala, S. (2018). Pendekatan \& Model Kepemimpinan . Jakarta: Prenadamedia Group.

Sagala, S. (2018). Pendekatan \& Model Kepemimpinan. Jakarta: Prenadamedia Group (Divisi Kencana).

Solihin, I. (2009). Pengantar Manajemen. Jakarta: Erlangga.

Sugiyono. (2012). Metode Penelitian Pendidikan: Pendekatan Kuantitatif, Kualitatif dan $R \& D$. Bandung: Alfabeta.

Suherman, A., Farida, S. I., Yuwono, T. I., Surasni, S., \& Sumali, A. I. (2020). BERBAGI BERSAMA UNTUK 30 WARGA YANG TERDAMPAK COVID-19 KELURAHAN BABAKAN. KOTA TANGERANG SELATAN, PROVINSI BANTEN. DEDIKASI PKM, 1(2), 1-5.

Sunardi, N. (2019). Relevansi Struktur Kepemilikan Tentang Profitabilitas Dan Nilai Perusahaan (Studi pada Industri Manufaktur yang Terdaftar di Bursa Efek Indonesia Periode 2010-2017). PROCEEDINGS UNIVERSITAS PAMULANG, 1(1).

Sunardi, N., \& Lesmana, R. (2020). Konsep Icepower (Wiramadu) sebagai Solusi Wirausaha menuju Desa Sejahtra Mandiri (DMS) pada Masa Pandemi Covid19. JIMF (Jurnal IImiah Manajemen Forkamma), 4(1).

Sutrisno, E. (2017). Manajemen Sumber Daya Manusia. Jakarta: Kencana Prenadamedia Group.

Tersiana, A. (2018). Metode Penelitian. Yogyakarta: Start Up.

Thoha, M. (2017). Kepemimpinan dalam Manajemen. Depok: PT Rajagrafindo Persada.

Thoha, M. (2017). Kepemimpinan dalam Manajemen. Depok: PT. Rajagrafindo Persada.

tribunnews.com. (2019, Oktober 14). tribunnews.com. Retrieved Oktober 14, 2019, from https://rumah-baca2.blogspot.com/2019/10/rumah-sakit-jiwa-di-jawa-baratmulai.html?m=1

Ulum, M. K., \& Suharningsih. (2016). Strategi Pramuka Saka Bhayangkara dalam Upaya Membangun Jiwa Kepemimpinan Remaja di Polsek Kutorejo Kabupaten Mojokerto. Kajian Moral dan Kewarganegaraan. Vol 3 No 4, 1937-1947.

Wijaya, C., \& Rifa'i, M. (2016). Dasar-Dasar Manajemen (Mengoptimalkan Pengelolaan Organisasi secara Efektif dan Efisien). Medan: Perdana Publishing.

Yani, F. (2011). Pengaruh Kecerdasan Intelektual, Kecerdasan Emosional, Kecerdasan Spiritual terhadap Pemahaman Akuntansi. Jurnal Akuntansi Pendidikan Universitas Riau. 